\title{
Mutation of the nm23-H1 gene has a non-dominant role in colorectal adenocarcinoma
}

\author{
YUELING JIN $^{1}$ and ZHENSHENG DAI ${ }^{2}$ \\ ${ }^{1}$ Department of Pathology, Shanghai University of Medicine and Health Sciences, Shanghai 200237; \\ ${ }^{2}$ Department of Hematology-Oncology, Shanghai Pudong Hospital Affiliated to Fudan University, Shanghai 201399, P.R. China
}

Received March 17, 2015; Accepted April 7, 2016

DOI: $10.3892 /$ mco.2016.889

\begin{abstract}
Nm23-H1 is a metastasis suppressor gene, which is has a reduced expression in patients with digestive system cancer. However, the mechanistic basis for the genetic instability remains unknown. To study the expression of the nm23-H1 gene in patients with colorectal cancer, polymerase chain reaction-single strand conformation polymorphism was used to analyze any point mutation, and immunohistochemistry was used to detect the expression of nm23-H1. Results revealed that all 63 specimens of Chinese human colorectal cancer tissues exhibit no point mutation. Among those $63 \mathrm{spec}-$ imens, 19 (30\%) exhibited positive immunostaining for the nm23-H1 protein and $44(70 \%)$ exhibited negative immunostaining. These observations suggested that the protein and gene expression levels of $\mathrm{nm} 23-\mathrm{H} 1$ are reduced in colorectal cancer compared with the adjacent normal tissues, and the point mutation in the $\mathrm{nm} 23-\mathrm{H} 1$ gene is not the dominant cause of metastatic colorectal cancer.
\end{abstract}

\section{Introduction}

Metastasis is one of the biological features of malicious cancer, and is one the causes of mortality as a result of colon cancer. The mechanism of metastasis is always the hot-spot of molecular biology research. Previous evidence shows that during the metastasis of malicious cancer, numerous genes are involved in the control and regulation at various levels. To date, researchers have identified that numerous genes can suppress cancer metastasis, including nm23, multiple cancer inhibition suppressor gene-1 and DLC-1 $(1,2)$. The nm23/NDP kinase is known as a non-metastasis gene, since Steeg et al (3) identified it from murine K-1735 melanoma cell lines in

Correspondence to: Dr Zhensheng Dai, Department of Hematology-Oncology, Shanghai Pudong Hospital Affiliated to Fudan University, 2008 Gongwei Road, Huinan, Shanghai 201399, P.R. China

E-mail: zhenshengdai@126.com

Key words: nm23-H1 gene, mutation, metastasis, colorectal adenocarcinoma
1988, Subsequently, Biggs et al (4) reported that the microtubule-associated abnormal wing disc gene (Awd)/NDP kinase is critical in spindle microtubule polymerization, and the product of awd of Drosophila is $78 \%$ identical to the product of the nm23 gene of mammals. In the following decades, the nm23 gene was further investigated and it was shown that suppression of metastatic mechanism of human nm23 in various cancer types may be through a dynamin-mediated pathway (5). The nm23 gene regulates cell invasion, cell differentiation and motility via the regulation of growth factor receptor signaling $(6,7)$. In 2013, the expression in chronic myelogenous leukemia cells was detected, and revealed that the nm23-H1 gene may inhibit K562 cell proliferation and migration (8). In order to further assess the role of the nm23-H1 gene mutation in colon cancer evolution, the present study used the polymerase chain reaction-single strand conformation polymorphism (PCR-SSCP)-silver staining method to detect changes in the nm23 gene in the colon cancer tissue, and an immunohistochemistry assay to analyze the protein expression of $\mathrm{nm} 23$ in patient samples.

\section{Patients and methods}

Patient samples. The present study obtained 63 specimens of human colorectal cancer tissue from Shanghai Pudong Hospital Affiliated to Fudan University (Shanghai, China), which were all diagnosed pathologically. Of these, 20 (32\%) exhibited lymph gland metastasis. The pathological types classification were as follows: $3(5 \%)$ cases of high differentiation gland cancer, $56(89 \%)$ cases of medium differentiation gland cancer and $4(6 \%)$ cases of low differentiation gland cancer. The present study was approved by the Ethics Committee of Shanghai Pudong Hospital Affiliated to Fudan University.

DNA-extraction. The genomic DNA extraction of fresh cancer tissue was performed using standard methods. The DNAwas isolated by digestion with Proteinase K (Takara Bio, Inc., Shiga, Japan) followed by phenol:chloroform (1:1) (Takara Bio, Inc.) extraction. Briefly, the cancer tissue was mashed up, and mixed with $10 \%$ sodium dodecyl sulfate and protein enzyme K (10 g/l) (Takara Bio, Inc.) for digestion at $55^{\circ} \mathrm{C}$ for $3 \mathrm{~h}$. Precipitation was performed using $\mathrm{NaCl}$ adn the samples were centrifuged at $81,600 \mathrm{x} g$ for $20 \mathrm{mins}$. The upper 
Table I. Primers used and PCR amplification conditions.

\begin{tabular}{|c|c|c|c|}
\hline Primer & Sequence $\left(5^{\prime} \rightarrow 3^{\prime}\right)$ & Conditions & $\begin{array}{l}\text { Size of amplified } \\
\text { products (bp) }\end{array}$ \\
\hline Exons 2 & $\begin{array}{l}\text { TGTTTCATTCCTCTACCTGC } \\
\text { GTTCTCCTATACTATGAAGG }\end{array}$ & $\begin{array}{l}95^{\circ} \mathrm{C} \text { for } 5 \mathrm{~min} \\
\left(95^{\circ} \mathrm{C} \text { for } 45 \mathrm{sec}, 52^{\circ} \mathrm{C} \text { for } 45 \mathrm{sec}, 72^{\circ} \mathrm{C} \text { for } 60 \mathrm{sec}\right) \times 32 \\
72 / 5 \mathrm{~min}\end{array}$ & 171 \\
\hline Exons 3 & $\begin{array}{l}\text { GTTATTCTCATTCTCTGTCC } \\
\text { CATACTTGGAGTATCCCAC }\end{array}$ & $\begin{array}{l}95^{\circ} \mathrm{C} \text { for } 5 \mathrm{~min} \\
\left(95^{\circ} \mathrm{C} \text { for } 45 \mathrm{sec}, 52^{\circ} \mathrm{C} \text { for } 45 \mathrm{sec}, 72^{\circ} \mathrm{C} \text { for } 60 \mathrm{sec}\right) \times 32 \\
72^{\circ} \mathrm{C} \text { for } 5 \mathrm{~min}\end{array}$ & 128 \\
\hline Exons 4 & $\begin{array}{l}\text { GACCATATCTTCTTCTGTCC } \\
\text { CCTTGTGGCAACTAAATCAG }\end{array}$ & $\begin{array}{l}95^{\circ} \mathrm{C} \text { for } 5 \mathrm{~min} \\
\left(95^{\circ} \mathrm{C} \text { for } 45 \mathrm{sec}, 53^{\circ} \mathrm{C} \text { for } 45 \mathrm{sec}, 72^{\circ} \mathrm{C} \text { for } 60 \mathrm{sec}\right) \times 32 \\
72^{\circ} \mathrm{C} \text { for } 5 \mathrm{~min}\end{array}$ & 154 \\
\hline Exons 5 & $\begin{array}{l}\text { GTCTTGGTCATGTGACTATC } \\
\text { GTGAAAAGCAATGTGGTCTG }\end{array}$ & $\begin{array}{l}95^{\circ} \mathrm{C} \text { for } 5 \mathrm{~min} \\
\left(95^{\circ} \mathrm{C} \text { for } 45 \mathrm{sec}, 53^{\circ} \mathrm{C} \text { for } 45 \mathrm{sec}, 72^{\circ} \mathrm{C} \text { for } 60 \mathrm{sec}\right) \times 32 \\
72^{\circ} \mathrm{C} \text { for } 5 \mathrm{~min}\end{array}$ & 141 \\
\hline
\end{tabular}

clear liquid layer was obtained and $700 \mathrm{ml} / 1$ cool alcohol was added for $20^{\circ} \mathrm{C}$ for 30 mins. The samples were centrifuged at $142,800 \mathrm{x}$ g for $10 \mathrm{mins}$. Phenol-chloroform and chloroform-isoamyl alcohol (Takara Bio, Inc.) were added separately and the samples were centrifuged at 132,600-153,000 x g for 5 mins. TE buffer (Takara Bio, Inc.) was added to dissolve and preserve the DNA.

PCR-SSCP.Four pairs of primers were designed, corresponding to the numbers 2-5 position exons of the nm23-H1 gene. PCR was performed, according to the stated conditions (Table I) on a Mastercycler Gradient PCR system (Eppendorf, Hamburg, Germany).

Following PCR, $10 \mu \mathrm{l}$ PCR product was added to the sample-loading buffer (Takara Bio, Inc.), including $950 \mathrm{~g} / \mathrm{l}$ formamide. The samples was denatured for $5 \mathrm{~min}$ at $95^{\circ} \mathrm{C}$, and was immediately put on ice. The denatured samples were separated by polyacrylamide gel electrophoresis in electrophoresis buffer $(0.5 \mathrm{X} \mathrm{TBE})$ at $70 \mathrm{~V}, 4^{\circ} \mathrm{C}$, overnight. Following running, silver staining (Wuhan Boster Company, Wuhan, China) was performed.

Immunohistochemistry. Rabbit polyclonal anti-nm23-H1 antibody and biotinylated goat anti-rabbit immunoglobulin $\mathrm{G}$ (each from Wuhan Boster Company) were used at concentrations of 1:50 and 1:500, respectively. The human colon tissue samples were preserved in $10 \%$ formaldehyde solution, and were dehydrated and embedded in paraffin, according to routine methods. Briefly, the $4 \mu \mathrm{m}$-thick paraffin sections were removed and blocked with $3 \%$ peroxide-methanol at room temperature for $20 \mathrm{~min}$ for endogenous peroxidase ablation. The sections were then incubated with the rabbit anti-nm23 antibody diluted in phosphate-buffered saline (PBS; $0.01 \mathrm{M}$; pH 7.4) for $2 \mathrm{~h}$ at $37^{\circ} \mathrm{C}$. Following incubation with primary antibody, the samples were incubated with goat anti-rabbit immunoglobulin $\mathrm{G}$ for $30 \mathrm{~min}$ at $37^{\circ} \mathrm{C}$. The samples were subsequently stained with 3,3-diaminobenzidine (Wuhan Boster Company) followed by washing in PBS. Nuclear counterstaining was performed using Mayer's

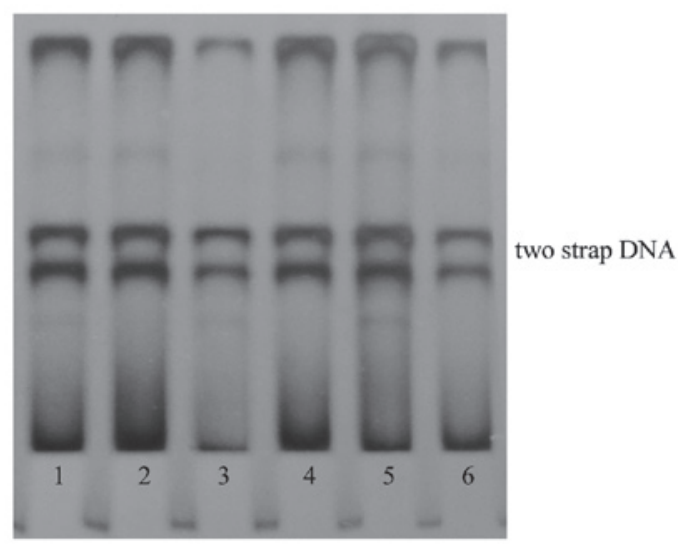

Figure 1. PCR-SSCP analysis of the colon cancer tissue (Samples 1-6). The DNA products of nm23 gene $4^{\text {th }}$ exon exhibit two straps following silver staining.

hematoxylin, followed by dehydration, clearing and mounted with neutral gums.

\section{Results}

PCR-SSCP. The present study performed PCR-SSCP detection on the 63 cases of colon cancer tissue specimens to analyze any point mutation of the $n m 23$ gene on the $2^{\text {nd }}-5^{\text {th }}$ exon position. Through repeated screening and operation, the results from the DNA samples revealed that the $2^{\text {nd }}-4^{\text {th }}$ exons of $n m 23-\mathrm{H} 1$ exhibit two straps (Fig. 1), but the $5^{\text {th }}$ exon displays four straps for certain specimens (data not shown). The coding protein was then analyzed and revealed that only the $5^{\text {th }}$ exon sequence of the nm23-H1 gene has a polymorphism. The $360^{\text {th }}$ position base exhibits a $\mathrm{T} \rightarrow \mathrm{C}$ replacement, but the coding amino acid $\mathrm{AGT} \rightarrow \mathrm{AGC}$ remains unchanged (serine), therefore, it is a synonymous mutation.

Immunohistochemistry. $\mathrm{nm} 23-\mathrm{H} 1$ is predominantly expressed in the cytoplasm of the colorectal cancer gland. Among 

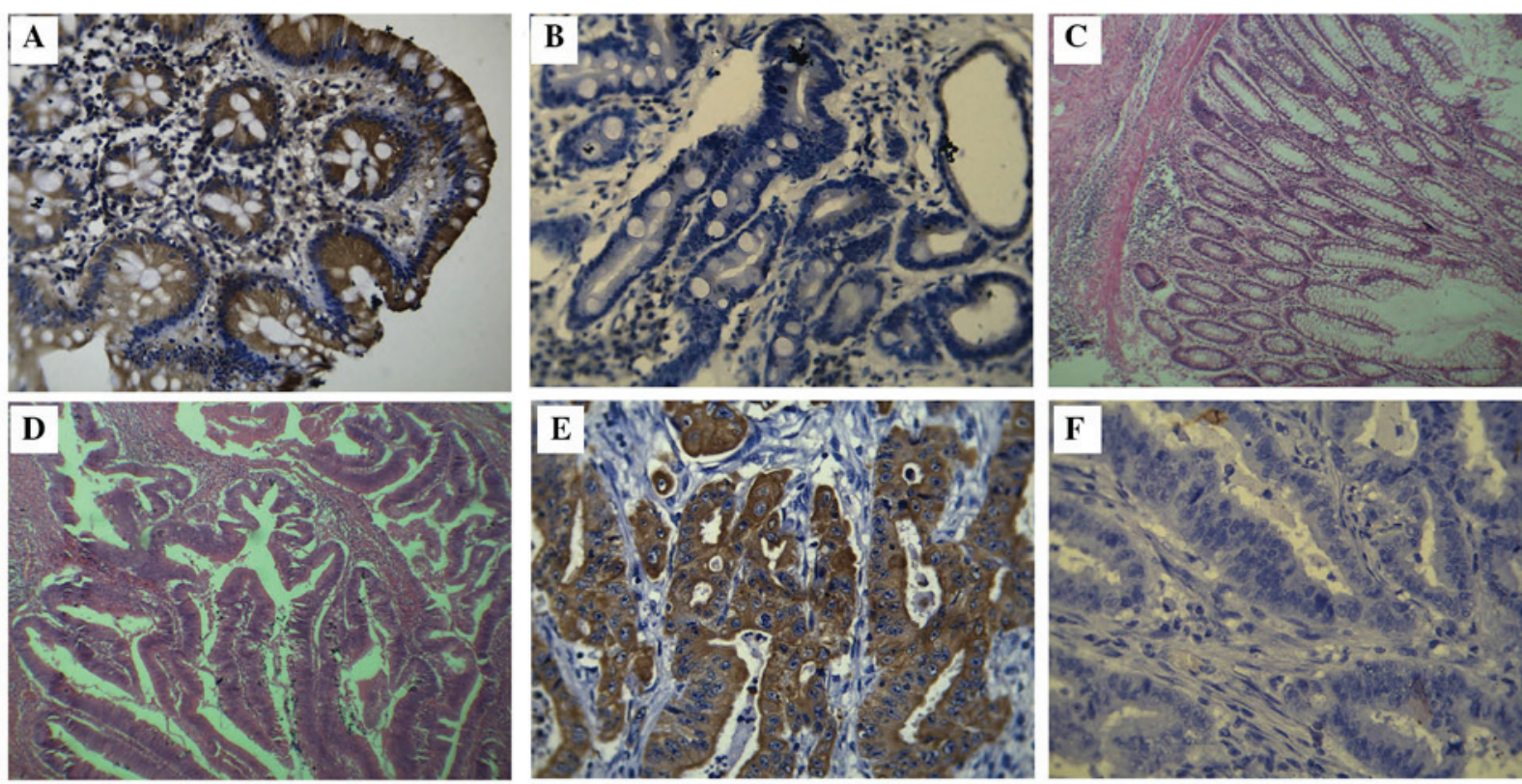

Figure 2. Microscopic assessment of colon tissue, both cancerous and non-cancerous (magnification, x400). (A) IH revealed positive cytoplasmic expression of $\mathrm{nm} 23$ in epithelial cells in normal colon mucosa. (B) IH revealed negative expression of nm23 in epithelial cells in colon mucosa. (C) H\&E staining revealed normal colon mucosa and (D) colon adenocarcinoma. (E) IH revealed positive cytoplasmic expression of nm23 in epithelial cells in colon cancer. (F) IH revealed negative expression of nm23 in epithelial cells in colon cancer. IH, immunohistochemistry; H\&E, hematoxylin and eosin.

the 63 colorectal adenocarcinomaspecimens, $19(30 \%)$ exhibited positive immunostaining for the nm23-H1 protein, $44(70 \%)$ exhibited negative immunostaining, while the adjacent normal tissues were $72 \%$ positive staining (Fig. 2).

\section{Discussion}

The $\mathrm{nm} 23$ gene has been regarded as a metastatic suppressive gene in various tumor types (9). It is an important cancer metastasis suppressor gene. The $\mathrm{nm} 23-\mathrm{H} 1$ gene cDNA has a total length of $534 \mathrm{bp}$ and 152 amino acids. The nm23 gene family has two homologous genes, nm23-H1 and nm23-H2, and both are located at $17 \mathrm{q} 22$, encoding a protein with a molecular weight of 18 and $17 \mathrm{kDa}$, respectively. The $\mathrm{nm} 23$ gene encodes a nucleoside diphosphate kinase (NDPK). Both $\mathrm{nm} 23-\mathrm{H} 1$ and $\mathrm{nm} 23-\mathrm{H} 2$ encode, the A and B subunits of NDPK, respectively. They are $88 \%$ identical in their amino acid sequences. NDPK activity is responsible for the synthesis of most cellular nucleoside triphosphates, other activities include cell proliferation, differentiation and development.

DR-nm 23 cDNA was cloned in 1997. It is highly homologous to the putative metastasis suppressor $\mathrm{nm} 23-\mathrm{H} 1$ gene and the closely associated $\mathrm{nm} 23-\mathrm{H} 2$ gene $(10,11)$. The expression of DR-nm23 in colorectal cancer tissue was significantly lower compared with that in adenoma and normal tissue. Therefore, the expression status of DR-nm23 may act as a potential prognostic factor in patients with colorectal cancer, and it may be involved in the regulation of differentiation of colorectal cancer cells (12). At the invasive front of colon carcinoma, $\mathrm{nm} 23-\mathrm{H} 1$ levels were also reduced or lost, and its downregulated expression was closely associated with the invasion and metastasis of colorectal cancer (13). The protein expression of nm23 was assessed in the colorectal carcinoma tissue by immunohistochemistry. This revealed that the protein expres- sion was higher in carcinoma tissue compared with that in adjacent non-neoplastic mucosa, similar to the results of a previous study (14).

In gastric and colorectal carcinomas, the genomic region $17 \mathrm{q} 21$ is frequently associated with microsatellite instability and loss-of-heterozygosity. The $\mathrm{nm} 23$ gene is located in this area. This region contains several putative tumor suppressor genes, including the Spn gene. Spn downregulation is associated with a poorer survival in patients with advanced stages of colorectal carcinoma (15), and downregulation of $\mathrm{nm} 23-\mathrm{H} 1$ contributes to tumorigenesis in lung cancer (16). Also, Qin et al (17) support the potential utility of targeting $\mathrm{Nm} 23-\mathrm{H} 1$ as a therapeutic approach for the treatment of Kaposi's sarcoma (17).

Data from a previous study has suggested that part of the antimetastatic function of Nm23-H1 lies in the pathways that it interrupts via binding and inactivation of proteins (18). In human hepatoma and colon carcinoma cells, nm23-H1 was implicated as a metastasis suppressor, in maintaining adherens junctions and limiting the invasive potential. It appears that $\mathrm{nm} 23$ is crucial for inhibiting invasive migration, cell-cell adhesion and cell migration (13). Enhanced expression of $\mathrm{nm} 23-\mathrm{H} 1$ protein in Chinese patients with digestive system cancer inhibited cancer metastasis (19). However, the mechanistic basis of the metastasis suppressor function of $\mathrm{nm} 23$ and its regulated expression remains to be elucidated.

Disorders of gene structure or gene expression can cause abnormalities in cell growth and differentiation, thereby causing cancer and having a malicious biological behavior. Generally, these are mechanisms that lead to gene silencing, mutation, genomic deletion and promoter methylation. Mutation screening is always performed by PCR-SSCP. At present, this technique has been used for detecting the known mutation hot-spots, screening of unknown mutations 
and analyzing of the gene mutation and cancer suppressing gene (20). The present study assessed 63 specimens of Chinese human colon cancer tissue via PCR-SSCP. The results indicated that the nm23 gene mutation does not serve the dominant role in the metastasis of colon cancer.

A previous study demonstrated that treatment with 5-aza-2-deoxycytidine reduces the expression of Nm23-H1, which causes hypermethylation in the nm23-H1 promoter $(17,21)$. Protein arginine methyltransferase 5 (PRMT5) methylates histones $\mathrm{H} 3$ at the $\mathrm{nm} 23$ promoter region and inhibits methylation of $\mathrm{H} 3 \mathrm{~K} 9$. PRMT5 regulates cell growth and proliferation by modulating the expression of nm23 (22). As with the previous studies, it is not possible to determine the mechanism of $n m 23$ responsible for the regulation of cell growth and proliferation involved in tumor suppression. The mechanisms by which nm23-H1 exerts its metastasis-suppressor functions involve multiple pathways, which remain to be elucidated $(23,24)$.

Although colon cancer metastasis may be due to other genes or due to the methylation of the control portion of nm23 gene, the mechanism of the nm23 as a suppressor gene is more complicated than previously hypothesized. Further research is required to fully understand the mechanism and to identify its role in the cancer process.

\section{Acknowledgements}

The present study was supported by Shanghai Pudong Science and Technology Commission of China. (no. PKJ2014-Y23).

\section{References}

1. Jin Y, Tian X, Shang Y and Huang P: Inhibition of DLC-1 gene expression by RNA interference in the colon cancer LoVo cell line. Oncol Rep 19: 669-674, 2008.

2. Dai Z and Jin Y: Promoter methylation of the DLC-1 gene and its inhibitory effect on human colon cancer. Oncol Rep 30: 1511-1517, 2013.

3. Steeg PS, Bevilacqua G, Kopper L, Thorgeirsson UP, Talmadge JE, Liotta LA and Sobel ME: Evidence for a novel gene associated with low tumor metastatic potential. J Natl Cancer Inst 80: 200-204, 1988.

4. Biggs J, Hersperger E, Steeg PS, Liotta LA and Shearn A: A drosophila gene that is homologous to a mammalian gene associated with tumor metastasis codes for a nucleoside diphosphate kinase. Cell 63: 933-940, 1990.

5. Dammai V, Adryan B, Lavenburg KR and Hsu T: Drosophila awd, the homolog of human nm23, regulates FGF receptor levels and functions synergistically with shi/dynamin during tracheal development. Genes Dev 17: 2812-2824, 2003.

6. Nallamothu G, Woolworth JA, Dammai V and Hsu T: Awd, the homolog of metastasis suppressor gene Nm23, regulates drosophila epithelial cell invasion. Mol Cell Biol 28: 1964-1973, 2008.

7. Nallamothu G, Dammai V and Hsu T: Developmental function of Nm23/awd: A mediator of endocytosis. Mol Cell Biochem 329: 35-44, 2009.

8. Dai Z, Xiao W and Jin Y: Inhibition of nm23-H1 gene expression in chronic myelogenous leukemia cells. Oncol Lett 6: 1093-1097, 2013.
9. Mitre-Aguilar IB, Cabrera-Quintero AJ and Zentella-Dehesa A: Genomic and non-genomic effects of glucocorticoids: Implications for breast cancer. Int J Clin Exp Pathol 8: 1-10, 2015.

10. Martinez R, Venturelli D, Perrotti D, Veronese ML, Kastury K, Druck T, Huebner K and Calabretta B: Gene structure, promoter activity, and chromosomal location of the DR-nm23 gene, a related member of the nm23 gene family. Cancer Res 57: 1180-1187, 1997.

11. McDermott WG, Boissan M, Lacombe ML, Steeg PS and Horak CE: Nm23-H1 homologs suppress tumor cell motility and anchorage independent growth. Clin Exp Metastasis 25: 131-138, 2008.

12. Qu L, Liang L, Su J and Yang Z: Inhibitory effect of upregulated DR-nm23 expression on invasion and metastasis in colorectal cancer. Eur J Cancer Prev 22: 512-522, 2013.

13. Boissan M, De Wever O, Lizarraga F, Wendum D, Poincloux R, Chignard N, Desbois-Mouthon C, Dufour S, Nawrocki-Raby B, Birembaut $\mathrm{P}$, et al: Implication of metastasis suppressor nm23-H1 in maintaining adherens junctions and limiting the invasive potential of human cancer cells. Cancer Res 70: 7710-7722, 2010.

14. Oliveira LA, Artigiani-Neto R, Waisberg DR, Fernandes LC, Lima Fde $\mathrm{O}$ and Waisberg J: nm 23 protein expression in colorectal carcinoma using TMA (tissue microarray): Association with metastases and survival. Arq Gastroenterol 47: 361-367, 2010.

15. Estevez-Garcia P, Lopez-Calderero I, Molina-Pinelo S Muñoz-Galvan S,Salinas A, Gomez-Izquierdo L,Lucena-Cacace A, Felipe-Abrio B, Paz-Ares L, Garcia-Carbonero R and Carnero A: Spinophilin loss correlates with poor patient prognosis in advanced stages of colon carcinoma. Clin Cancer Res 19: 3925-3935, 2013.

16. Molina-Pinelo S, Ferrer I, Blanco-Aparicio C, Peregrino S, Pastor MD, Alvarez-Vega J, Suarez R, Verge M, Marin JJ, Hernandez-Losa J, et al: Down-regulation of spinophilin in lung tumours contributes to tumourigenesis. J Pathol 225: 73-82, 2011.

17. Qin Z, Dai L, Toole B, Robertson E and Parsons C: Regulation of Nm23-H1 and cell invasiveness by Kaposi's sarcoma-associated herpesvirus. J Virol 85: 3596-3606, 2011.

18. Marino N, Marshall JC and Steeg PS: Protein-protein interactions: A mechanism regulating the anti-metastatic properties of Nm23-H1. Naunyn Schmiedebergs Arch Pharmacol 384: 351-362, 2011.

19. Yang YQ, Wu L, Chen JX, Sun JZ, Li M, Li DM, Lu HY, Su ZH, Lin XQ and Li JC: Relationship between nm23H1 genetic instability and clinical pathological characteristics in Chinese digestive system cancer patients. World J Gastroenterol 13: 5549-5556; discussion 5555, 2008.

20. Piwkham D, Siriboonpiputtana T, Beuten J, Pakakasama S, Gelfond JA, Paisooksantivatana K, Tomlinson GE and Rerkamnuaychoke B: Mutation screening and association study of the Folylpolyglutamate Synthetase (FPGS) gene with susceptibility to childhood acute lymphoblastic leukemia. Asian Pac J Cancer Prev 16: 4727-4732, 2015.

21. Hartsough MT, Clare SE, Mair M, Elkahloun AG, Sgroi D, Osborne CK, Clark G and Steeg PS: Elevation of breast carcinoma Nm23-H1 metastasis suppressor gene expression and reduced motility by DNA methylation inhibition. Cancer Res 61: 2320-2327, 2001

22. Pal S, Vishwanath SN, Erdjument-Bromage H, Tempst P and Sif S: Human SWI/SNF-associated PRMT5 methylates histone $\mathrm{H} 3$ arginine 8 and negatively regulates expression of ST7 and nm23 tumor suppressor genes. Mol Cell Biol 24: 9630-9645, 2004.

23. Marino N, Nakayama J, Collins JW and Steeg PS: Insights into the biology and prevention of tumor metastasis provided by the $\mathrm{Nm} 23$ metastasis suppressor gene. Cancer Metastasis Rev 31: 593-603, 2012.

24. Esposito S, Russo MV, Airoldi I, Tupone MG, Sorrentino C, Barbarito G, Di Meo S and Di Carlo E: SNAI2/Slug gene is silenced in prostate cancer and regulates neuroendocrine differentiation, metastasis-suppressor and pluripotency gene expression. Oncotarget 6: 17121-17134, 2015. 